\title{
High-Molecular-Weight Glutenin Subunits: Genetics, Structures, and Relation to End Use Qualities
}

\author{
Yi Li ${ }^{1,2,+}$, Jiahui Fu ${ }^{1,+}$, Qun Shen ${ }^{3}$ (D) and Dong Yang ${ }^{1,2, *(D)}$ \\ 1 Beijing Key Laboratory of Functional Food from Plant Resources, College of Food Science \& Nutritional \\ Engineering, China Agricultural University, 17 East Tsinghua Rd., Beijing 100083, China; \\ sy20193061047@cau.edu.cn (Y.L.); s20193060969@cau.edu.cn (J.F.) \\ 2 Xinghua Industrial Research Centre for Food Science and Human Health, China Agricultural University, \\ Xinghua 225700, China \\ 3 Key Laboratory of Plant Protein and Grain Processing, National Engineering Research Center for Fruit and \\ Vegetable Processing, China Agricultural University, 17 East Tsinghua Rd., Beijing 100083, China; \\ shenqun@cau.edu.cn \\ * Correspondence: dyang@cau.edu.cn; Tel.: +86-10-6273-7129 \\ + These authors share equal co-first contribution.
}

check for

updates

Citation: Li, Y.; Fu, J.; Shen, Q.; Yang, D. High-Molecular-Weight Glutenin Subunits: Genetics, Structures, and Relation to End Use Qualities. Int. J. Mol. Sci. 2021, 22, 184. https:// dx.doi.org/10.3390/ijms22010184

Received: 26 November 2020 Accepted: 23 December 2020 Published: 26 December 2020

Publisher's Note: MDPI stays neutral with regard to jurisdictional claims in published maps and institutional affiliations.

Copyright: (C) 2020 by the authors. Licensee MDPI, Basel, Switzerland. This article is an open access article distributed under the terms and conditions of the Creative Commons Attribution (CC BY) license (https: / / creativecommons.org/ licenses/by/4.0/).

\begin{abstract}
High-molecular-weight glutenin subunits (HMW-GSs) are storage proteins present in the starchy endosperm cells of wheat grain. Encoding the synthesis of HMW-GS, the Glu-1 loci located on the long arms of group 1 chromosomes of the hexaploid wheat $(1 \mathrm{~A}, 1 \mathrm{~B}$, and $1 \mathrm{D})$ present multiple allelism. In hexaploid wheat cultivars, almost all of them express 3 to 5 HMW-GSs and the 1Ay gene is always silent. Though HMW-GSs are the minor components in gluten, they are crucial for dough properties, and certain HMW-GSs make more positive contributions than others. The HMW-GS acts as a "chain extender" and provides a disulfide-bonded backbone in gluten network. Hydrogen bonds mediated by glutamine side chains are also crucial for stabilizing the gluten structure. In most cases, HMW-GSs with additional or less cysteines are related to the formation of relatively more or less interchain disulfide bonds and HMW-GSs also affect the gluten secondary structures, which in turn impact the end use qualities of dough.
\end{abstract}

Keywords: HMW-GS; end use qualities; interchain disulfide bonds; secondary structures

\section{Introduction}

Wheat is one of the most widely grown cereal crops worldwide with hexaploid wheat (Triticum aestivum L., AABBDD) being a representative one. According to the Agricultural Market Information System (AMIS), the estimate of world wheat production is 764.9 million tons in 2020 to 2021 [1]. Take China as an example, as the world's largest wheat producer, China produced 131 million tons of wheat and consumed 128 million tons in 2019, among which $67.7 \%$ was used for food and $15.0 \%$ was used for feed [2]. Protein makes up approximately $8 \%$ to $20 \%$ of the total mass of mature wheat grains [3]. Based on their solubility, protein in wheat grain can be categorized into four classes: albumin, globulin, gliadin, and glutenin [4]. The latter two, gliadin and glutenin, are the major components of gluten, which are similar in content and together accounts for approximately $80-85 \%$ of wheat protein [3]. The protein of wheat grain, especially gluten protein, is generally regarded as one of the most important factors determining dough properties and bread qualities [5-7].

Defined as the remaining rubbery mass after gently washing wheat dough to remove the bulk starch granules and water-soluble components, gluten usually contains approximately $75-85 \%$ protein on a dry weight basis, depending on the thoroughness of washing [8]. Glutenin subunits are the monomeric component of a gluten polymer in dough through covalent disulfide linkage and noncovalent interactions including hydrogen bonding and hydrophobic interaction, forming a tight gluten network backbone and 
providing dough elasticity as well as dough strength. On the other hand, most gliadins exist in their monomeric form, affording dough viscosity and extensibility via electrostatic interactions and hydrogen bonding $[9,10]$. Gliadins can be further separated from gluten by dissolving in $60 \%$ to $70 \%(v / v)$ ethanol solution. Besides, the solubility of glutenin subunits from gluten would be similar to gliadins in aqueous alcohols if the disulfide bonds are reduced [8]. Based on their electrophoresis mobility on a sodium dodecyl sulfate-polyacrylamide gel electrophoresis (SDS-PAGE), reduced glutenin from dough can be further categorized into High-molecular-weight glutenin subunits (HMW-GSs, MW of 67,000-90,000 Da) and low-molecular-weight glutenin subunits (LMW-GSs, MW of 30,000-45,000 Da) [11-14]. Though HMW-GSs are minor components in terms of mass (approximately 10\% of gluten protein), they are highly related to end use quality [8]. This review aims to describe the genetics and different levels of structures of HMW-GS, and their relationships to dough and bread-making qualities.

\section{Genetics of HMW-GS}

It is now firmly established that genes named Glu-1 loci encoding the synthesis of HMW-GS (Glu-A1, Glu-B1, and Glu-D1) are located on the long arms of group 1 chromosomes of the hexaploid wheat (1A, 1B, and 1D) (Figure 1) [15-18]. Each locus includes 2 genes linked together encoding 2 different types of HMW-GS, the x-type subunits with a relatively higher molecular weight and the y-type subunits which exhibit relatively higher electrophoretic mobility on the SDS-PAGE [12-14,19-21]. Moreover, subloci differences are greater than homoeoallelic differences. For example, differences between Glu-D1x genes (genes encoding x-type subunits) and Glu-D1y genes (genes encoding y-type subunits) are greater than differences between Glu-D1y genes and Glu-B1y genes, as shown in Figure $2[22,23]$.

Long arm

1A

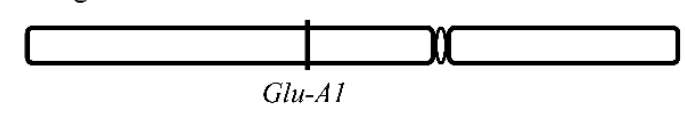

1B

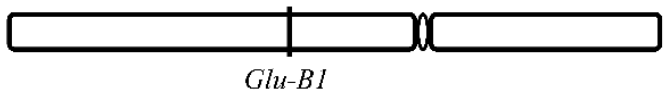

1D

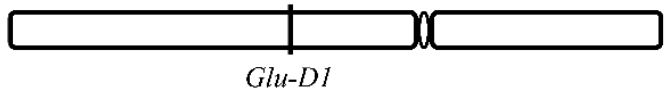

Figure 1. Schematic diagram of the gene loci of a high-molecular-weight glutenin subunit (HMW-GS) in wheat chromosome 1: the genes coding the synthesis of HMW-GS are located on the long arms of group 1 chromosomes 1A, 1B, and 1D.

\subsection{Allelic Variations of Glu-1 Loci}

The Glu-1 loci present multiple allelism: 3 alleles at the Glu-1A loci, 11 alleles at the Glu-1B loci, and 6 alleles at the Glu-1D loci were systematically reported by isolating HMW-GSs from SDS-PAGE in 1983, in which the numbering system developed to identify HMW-GS and provide a chromosomal location of the genes is currently still in use [24]. Polymerase chain reaction (PCR) and immunoassay using specific monoclonal antibodies are alternative ways of isolating novel genes encoding HMW-GS [25-28]. Since the publication of the catalog of gene symbols for wheat, more than 100 allelic variations at the Glu-1 loci have been identified [29]. According to the collections of the HMW-GS alleles from over 7830 cultivars/lines, there is no doubt that the Glu-1 loci exhibits high genetic polymorphisms [30]. In particular, the $G l u-1 B$ and $G l u-1 D$ alleles display higher variable frequency while that of the Glu-1A alleles is a much lower. Recently, a number of novel Glu-1 genes from wheat landraces or related species have been identified to be of potential application values to wheat breeding, and efforts have also been made to transfer desirable 
Glu-1 alleles to cultivated wheat by wide hybridization and chromosomal engineering approaches [14,31-36].

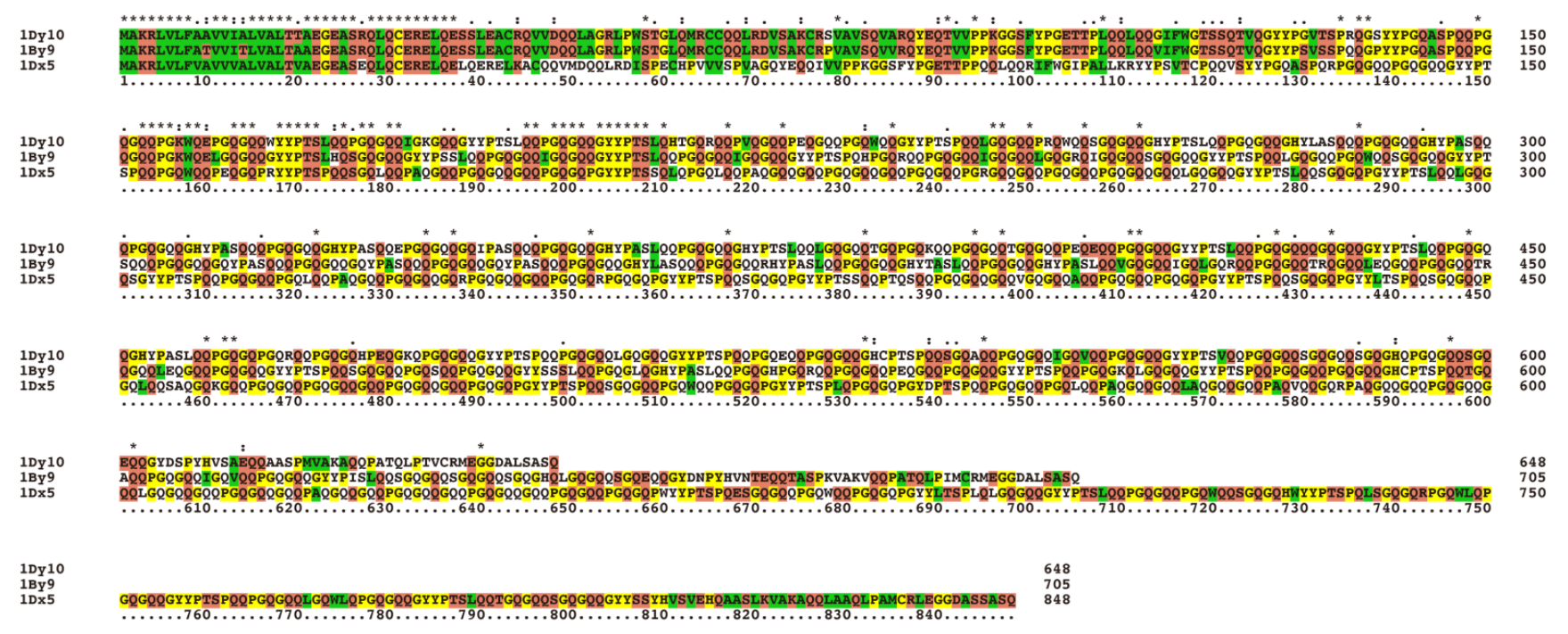

Figure 2. "** indicates identical amino acid residues, ":" indicates similar amino acid residues, and "." indicates less similar amino acid residues. Yellow indicates amino acid residues G, P, C, H, Y; red indicates amino acid residues T, S, N, Q, E, D, K, $\mathrm{R}$; green indicates amino acid residues $\mathrm{W}, \mathrm{L}, \mathrm{V}, \mathrm{I}, \mathrm{F}, \mathrm{A}, \mathrm{M}, \mathrm{C}$.

Working on HMW-GS allelic variations to improve wheat bread-making qualities has been an attractive research topic in the past several decades. Some allelic variations make greater contributions to dough elasticity and strength as well as loaf volume than others. In general, the Glu-D1 loci exhibited the most significant effect on dough and bread-making properties, followed by Glu-B1 and Glu-A1 [37-39]. Furthermore, several studies found that both Glu-D1 and Glu-B1 exhibit significant effects on dough qualities on their own, whereas the effects of Glu-A1 loci depend on the presence of other Glu-1 subunits [40].

As for specific alleles encoding HMW-GSs, the Glu-A1a allele encoding 1Ax1 and the Glu-D1d allele encoding 1Dx5 and 1Dy10 were reported to be associated with better bread-making qualities, and the beneficial effects of these two alleles are additive [19]. Later, in 1987, after analysis of 84 hexaploid wheat varieties, the Glu-1 quality scores assigned to each HMW-GS and corresponding alleles were reported. Among the alleles reported in the research, wheat containing the Glu-D1d allele encoding 1Dx5 and 1Dy10 represents the highest score, corresponding to higher bread-making qualities, while Glu$A 1 c$, Glu-B1a, Glu-B1d, and Glu-D1c represent the lowest scores, corresponding to poor bread-making qualities [16]. By comparing the rapid mix test score from 153 German wheat varieties, it was discovered that the bread-making quality was positively influenced by alleles encoding subunits $1 \mathrm{Ax} 1,1 \mathrm{Ax} 2^{*}, 1 \mathrm{Bx} 7+1 \mathrm{By} 9,1 \mathrm{Bx} 14+1 \mathrm{By} 15,1 \mathrm{Bx} 17+1 \mathrm{By} 18$, and $1 \mathrm{Dx} 5+1 \mathrm{Dy} 10$ [41]. Meanwhile, by studying the deletion of combinations of HMW-GS loci, contributions of each HMW-GS to dough processing properties were ranked in the following order: 1Dx5 + 1Dy10 > 1Bx17 + 1By18 > 1Ax1 + Null [40]. Nevertheless, several studies argue that all HMW-GSs contribute positively to dough or bread-processing quality but only differ in magnitude, since the absence of HMW-GS with weaker effects, such as $1 \mathrm{Dx} 2,1 \mathrm{Dy} 12,1 \mathrm{~B} \times 20$, and $1 \mathrm{By} 20$, also led to inferior flour-processing quality in wheat mutants [42-46].

\subsection{Gene Expression}

The mechanism that regulates HMW-GS expression remains largely unclear [47]. Some conserved cis-acting elements related to the expression of storage proteins have been identified in HMW-GS gene promoters [47-50]. To date, storage protein activator (SPA), a member of the basic leucine zipper (bZIP) family, has been identified to play a key role in 
the regulation of wheat grain storage protein synthesis [51-55]. From a theoretical point of view, the hexaploid wheat cultivars could express 6 different HMW-GSs, 1Ax, 1Ay, 1Bx, 1By, 1Dx, and 1Dy, while in fact, owing to gene silencing, almost all of them express 3 to 5 HMW-GSs depending on wheat cultivars except the few hexaploid wheat cultivars expressing all $6 \mathrm{HMW}-\mathrm{GSs}$ [56-58]. The expression frequencies of 1Dx, 1Dy, and 1Bx are usually the highest, while the 1Ax and 1By subunits sometimes are not expressed at all. On the other hand, the 1Ay subunit is often not expressed in the hexaploid wheat, whereas its expression is frequently reported in diploid and tetraploid wheat [19,59-61].

\subsubsection{Progress on the $A y$ Gene}

Since 1Ay genes show a high frequency of silence in the hexaploid wheat, researchers have focused on their promoters and coding region structures to explore probable causes. Comparing the $5^{\prime}$ upstream promoter region of the active gene encoding $1 \mathrm{By} 9$ with the same region from a silent y-type gene derived from chromosome 1A, it was discovered that there is a deletion of $85 \mathrm{bp}$ bases in the latter, which was also found in the $5^{\prime}$ upstream promoter region of the inactive Ay1d gene from the cultivated emmer (Triticum dicoccum, $2 n=4 \mathrm{x}=28$, AABB) [62,63]. However, analysis of 141 accessions of diploid and tetraploid wheats found this $85 \mathrm{bp}$ deletion to be present in the promoter regions of all $91 \mathrm{Ay}$ genes, regardless of whether these genes are active or not [64]. Researchers later constructed two promoter-GUS ( $\beta$-glucuronidase) reporter gene chimeric vectors, $\mathrm{pBI} 121-A y-G U S$ and $\mathrm{pBI} 121-\mathrm{Dx} 5-\mathrm{GUS}$, in which the native promoters were replaced by promoters from an inactive $1 A y$ gene and an active gene encoding $1 \mathrm{Dx} 5$, respectively. The transient expression of promoter-GUS constructs indicated that the $1 A y$ promoter can drive the expression of the GUS gene, verifying that $85 \mathrm{bp}$ deletion in the promoter is not associated with inactivation of $1 A y$ genes [60].

As for the coding region, an 8-kb insertion retroelement in a cloned pseudo $1 \mathrm{Ay}$ gene from wheat cultivar Chinese Spring (Triticum aestivum L., AABBDD), termed wheat insertion sequence-2 (Wis-2), was reported, which interrupts the coding sequence [62]. Similarly, the Ay gene coding sequence in a tetraploid wheat cultivar, T. turgidum (AABB), is also disrupted by an insertion of a Wis retroelement, Wis-3, which may result in silencing of the Ay gene [65]. Besides the above, many scholars have focused on the stop codons in the coding region as well. Translations of three silenced $A y$ genes from the diploid and tetraploid wheat species, together with silencing of $1 A y$ (from hexaploid wheat $\mathrm{cv}$. Cheyenne) were disrupted by premature stop codons [64]. This is consistent with a previous study showing that the coding region of an inactive $A y$ gene, namely $A y 1^{d}$, contains four stop codons [63]. In conclusion, these genes were highly unlikely to be expressed with full length and defects in the coding regions could be responsible for silencing of the $1 \mathrm{Ay}$ genes.

Since the Glu-1Ay gene is usually silenced in hexaploid wheat, the utilization of active $1 A y$ genes might be an effective strategy for improving flour quality. An active allele encoding 1 Ay subunits was successfully integrated from wild emmer wheat (Triticum turgidum ssp. dicoccoides) into the hexaploid wheat (Triticum aestivum) [66]. In this study, the selected line TaAy7-40, which expresses 1Ay subunits stably, was reported to possess better processing quality. Two Swedish hexaploid wheat lines (W29323 and W3879) were found to contain both active $1 A x$ and $1 A y$ genes and the corresponding expressed subunits were initially named $21^{*}$ and $21^{*} \mathrm{y}$, which were later found inherited as a pair [57]. Moreover, the allele encoding $1 \mathrm{Ax} 21^{*}$ and $1 \mathrm{Ay} 21^{*}$ were also integrated into two Australian wheat cultivars and was found to have no significant alterations in their agronomic traits. However, the integration of the Ay subunit showed positive effects in protein and gluten content, protein composition, dough mixing properties, and Zeleny sedimentation values [67]. In 2019, scholars reported that expression of the gene encoding $1 \mathrm{Ay} 21^{*}$ has the potential to simultaneously increase protein content and grain yield under certain environment [68]. Thus, the active $G l u-1 A y$ allele might be of potential value in breeding aiming to improve wheat flour quality. 


\subsubsection{Progress on the $B x 7$ Gene}

Among various kinds of alleles, researchers discovered a unique Glu-B1al allele encoding overexpression of $1 \mathrm{~B} \times 7\left(\mathrm{Bx} 7^{\mathrm{OE}}\right)$. This allele is highly associated with improved dough strength, which has been found in many cultivars and landraces [69-73]. However, an Australian cultivar H45, though confirmed to overexpress Bx7 subunits, had relatively low un-extractable polymeric gluten (an indicator of weak dough), the corresponding allele of which was then designated as Glu-B1br [74].

Compared to the gene encoding normal $1 \mathrm{Bx} 7$ subunits, the gene encoding $1 \mathrm{Bx} 7^{\mathrm{OE}}$ shows an $18 \mathrm{bp}$ nucleotide duplication in the coding region and a $43 \mathrm{bp}$ insertion in the matrix-attachment region (MAR) upstream to the gene promoter $[75,76]$. However, evidence indicated that these 18- and 43-bp sequence insertions are not associated with the high expression levels of $1 \mathrm{Bx} 7$ because the 18- and 43-bp indels were also found in accessions other than $\mathrm{B} \times 7^{\mathrm{OE}}$ [77]. There is also evidence that the Glu-B1al allele includes two copies of its $x$-type glutenin gene [71]. Later, by sequencing a bacterial artificial chromosome (BAC) clone encompassing the Glu-B1 locus, scholars reported a 10.3-kb segmental duplication including the $B \times 7$ gene and a flanking long terminal repeat (LTR) retroelement [78]. Meanwhile, according to research collecting a large amount of diploid, tetraploid, and hexaploid accessions, the LTR retroelement/duplication genomic structure was not found in accessions without Bx7 overexpression. These results indicated that gene duplication at the Glu-B1 locus mediated by insertion of a retroelement may lead to overexpression of the Bx7 subunits [77].

\section{Structures of HMW-GS}

\subsection{The Primary Structures}

The mature HMW-GSs consist of three structural domains: a nonrepetitive N-terminal domain comprising approximately 81-104 residues and a C-terminal domain of 42 residues, flanking a repetitive central domain with 481 to 872 residues [79]. The repetitive central domain, as the largest part of HMW-GS, is identified by three types of primary repeat units in the $x$-type subunits and two types of primary repeat units in the y-type subunits. In the x-type subunits, the repeat units are the tripeptides (GQQ), hexapeptides (PGQGQQ), and nonapeptides (GYYPTSPQQ). In the y-type subunits, the repeat units are the hexapeptides (PGQGQQ) and nonapeptides (GYYPTSLQQ) [80-82]. Note that the tripeptide and hexapeptides of the $\mathrm{x}$-type subunit are always present in tandem with each other [83]. While the $\mathrm{N}$ - and C-terminal regions are quite conservative, variations in the central repetitive domain, particularly the number of tripeptides and hexapeptides, are the main causes of differences in subunit size $[79,82,84,85]$. Meanwhile, as indicated by the amino acid composition, the central repetitive domain exhibited hydrophilic properties while the N-terminal and C-terminal domain exhibited hydrophobic characteristics [81,82]. A recent study shows that the central repetitive domain could be folded in the action of wheat protein disulfide isomerase, which serves as the basis of dough extension [86].

\subsection{Cysteine Residues and Disulfide Bonds}

The distribution of cysteine residues in typical $x$-type and y-type subunits are shown in Figure 3. In general, most x-type subunits contain four cysteines, three in the N-terminal domain and one in the C-terminal domain $[31,82]$. The $1 \mathrm{Dx} 5$ subunit contains an additional cysteine at the beginning of the repetitive domain, while the 1Bx14 and 1Bx20 subunits contain only two cysteine residues, one in the N-terminal region and the other in the C-terminal domain [87-91]. A typical y-type subunit contains seven cysteines: five in $\mathrm{N}$-terminal domains, one in the central repetitive domain, and one in the C-terminal domain [22,31]. Cysteine residues in the central domain of all y-type subunits usually do not exist in the $x$-type subunits. 


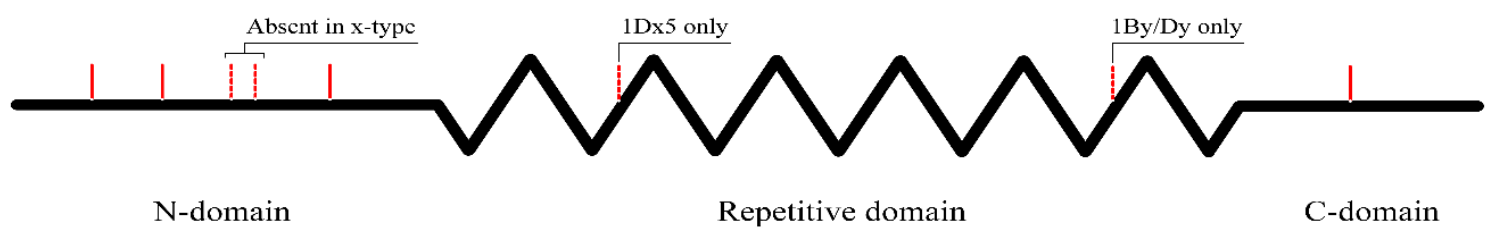

Figure 3. Schematic representation of the distribution of cysteine residues in $x$ - and y-type HMW-GSs: the HMW-GS is comprised of three domains, the N- and C- terminal domains where most cysteine residues (red lines) are located, flanking a central repetitive domain. Two cysteine residues in the N-terminal of the y-type HMW-GSs are absent in the $x$-type. In HMW-GS 1Dx5, there is one additional cysteine residue in the repetitive domain near the N-terminal side, and there is an additional cysteine residue in the repetitive domain of the HWM-GSs 1By and 1Dy near the C-terminal side.

Though cysteines are less abundant in HMW-GS, they are extremely crucial to the structure and functions of gluten [92]. Cysteines in the HMW-GSs form either intrachain disulfide bonds or interchain disulfide bonds with other HMW-GSs or LMW-GSs through oxidation, e.g., by catalysis of wheat protein disulfide isomerase $[6,83,93,94]$. In general, the HMW-GS acts as the "chain extender" of the gluten network owing to the fact that, in most cases, each HMW-GS can provide at least two cysteines participating in the formation of interchain disulfide bonds to form larger gluten aggregates, and it can be further improved by the addition of a so-called flour improver, which are oxidants in nature (e.g., azodicarbonamide and ascorbic acid) [8,95]. According to a structural model for wheat gluten, the HMW-GS provides a disulfide-bonded backbone which forms the basis for "branches" of LMW-GS linked by interchain disulfide bonds and interacts with gliadins by noncovalent interactions [96]. In addition, interchain disulfide bonds play an important role in stabilizing HMW-GS polymers [97]. For these contributing to gluten formation, the disulfides bonds are called "rheologically active" and others are "rheologically inactive", and the former is catalyzed by wheat protein disulfide isomerase [98]. In FT-Raman Spectroscopy, the band appearing at $497 \mathrm{~cm}^{-1}$ is related to the interchain disulfide bond. Studies have shown that the content of interchain disulfide bond is positively associated with dough properties [99-101]. However, up to now, interchain bonds related to HMW-GS extracted from gluten have only been found: (1) between cysteines in a y-type HMW-GS $\mathrm{N}$-terminal domain and the corresponding residue of another y-type HMW-GS, which are connected in parallel; (2) between the cysteine of a y-type HMW-GS repetitive central domain and a cysteine in LMW-GS; (3) and between the additional cysteine of 1Dx5 and the cysteine of an $x$-type HMW-GS C-terminal domain. Intrachain disulfide bonds related to HMW-GS extracted from gluten have only been between the adjacent cysteines of the $\mathrm{N}$-terminal domain of 1Bx7, which is in line with a molecular model [102-105]. Other scholars have also proposed two possible patterns of disulfide bond formation according to the homology modeling and molecular dynamics simulations of the N-terminal domain of 1Dy10 [106]. Later in 2017, disulfide linkages in a recombinant N-terminal domain of 1Dx5 (1Dx5-N), which contains three cysteine residues (Cys10, Cys25, and Cys40), were dissected by site-directed mutagenesis and liquid chromatograph-mass spectrometer/mass spectrometry (LC-MS/MS). According to the LC-MS/MS results, intermolecular linkages were found in many combinations among Cys10, Cys25, and Cys40, indicating that the disulfide linkages between Cys10, Cys25, and Cys40 were not conserved strictly. Meanwhile, it was identified that Cys10 and Cys40 were the active sites for intermolecular linkages and that intramolecular linkages were only found between Cys 25 and Cys40, which is contradictory to a molecular model of $1 \mathrm{Dx} 5-\mathrm{N}$ with no formation of intramolecular disulfide bonds by prediction $[105,107]$. Besides, the addition of 1Dx5-N greatly enhanced the formation of a gluten network through disulfide bonds cross-linking and hydrophobic interactions, which exerted a synergistic effect and thus contributed to the superior improvement in dough qualities [108].

It has been reported that, in most cases, HMW-GSs with additional or less cysteines were supposed to give rise to relatively higher or poorer qualities. The additional cysteine in 1Dx5, which might form another interchain bond, is supposed to be responsible for the 
superior bread properties exhibited in cultivars expressing 1Dx5 subunits [101,103,109]. As for HMW-GSs with less cysteine residues, scholars compared the effects of $1 \mathrm{Bx} 20$ subunit with two cysteine residues versus subunit $1 \mathrm{Bx} 7$ containing four cysteine residues and discovered that the wheat line carrying a 1Bx20 subunit exhibited less large glutenin polymer formation and poorer mixographic parameters [110]. Similar results have been obtained that incorporation of $1 \mathrm{~B} \times 20$ subunits to base flour only resulted in small effects, either positive or negative, on dough strength and stability [25]. Meanwhile, $1 \mathrm{Bx} 14^{*}$, which contains only two cysteine residues resulting in less formation of intermolecular disulfide bonds, is suggested to be partially the reason of poor milling quality [111]. These experiments fully demonstrated a role of the number of cysteine residues in determining the formation of glutenin polymers and subsequent rheology parameters of dough.

In addition to cysteine, glutathione (GSH), which is naturally present in wheat flour, also plays a critical role in polymerization. GSH contains one cysteine and can easily be oxidized to form GSSG or protein bound glutathione (PSSG, Equation (1)) [112].

$$
\mathrm{GSH}+\mathrm{PSSP} \rightarrow \mathrm{PSSG}+\mathrm{PSH}
$$

That is to say, GSH may cleave the SS bonds of glutenin polymers and promote free cysteine formation, resulting in the trigger of SH/SS interchange reactions. Meanwhile, GSSG reacts with free sulfhydryl groups of aggregated glutenins during polymerization and generates PSSG. Finally, the average molecular weight of gluten network proteins decreases and dough softening occurs [112,113].

\subsection{Secondary Structures of HMW-GS}

The N- and C-terminal domains are both considered to be rich in $\alpha$-helixes $[114,115]$. As for the central repetitive domains, $\beta$-reverse turns were initially proposed to be the dominant structural feature, as supported by the circular dichroism (CD) and Fourier transform infrared spectra (FTIR) study of synthetic peptides designed with the consensus peptides PGQGQQ and GYYPTSPQQ of HMW-GS [80,115-117]. These regularly repeated $\beta$-turns in the HMW-GS were organized into a $\beta$-spiral structure, supported by scanning tunneling microscopy images of 1Dx5 [116,118-120]. Analyses of the data from viscometric and small angle X-ray scattering also indicated that the structure of both reduced (no formation of disulfide bond) and alkylated HMW-GS are rod-shaped $[119,120]$. Despite $\beta$-turns, FTIR of HMW-GS in the hydrated solid state also indicated the presence of intermolecular $\beta$-sheet structures owing to the formation of extensive hydrogen bonds, which may be promoted by the N- and C-terminal domains $[114,119,120]$. The content of $\beta$-sheets was reported to change according to water content and temperature [121,122].

Although interchain disulfide bonds are crucial for stabilizing the HMW-GS polymers, nuclear magnetic resonance (NMR) studies indicate that hydrogen bonds mediated by glutamine side chains may also play an important role in stabilizing the gluten structure [121]. A "loop and train" model has been proposed for the contribution of such hydrogen bonding to gluten elasticity, in which HMW-GS has unbonded mobile regions (loops) and bonded regions (trains) at intermediate moisture contents [123]. The loops can be stretched, and when the stress is removed, reestablishment of the loop-train equilibrium provides the elastic restoring force; as a result, extension of the dough will result in stretching of the "loops" and "unzipping" of the "trains" [10]. The formation of interchain hydrogen bonds between glutamine residues may account for this observation as well $[124,125]$. Later, this model was further supported by many studies. NMR experiments showed that some parts of a purified HMW-GS chain were held in a much less mobile state, even at higher water contents [121]. According to the carbon and proton solid-state NMR study, regions rich in glutamine and glycine residues may form more mobile (or loop) parts of the network whereas regions containing high amount of hydrophobic residues intermingled with glutamines residues may form the junction zones (trains) [126]. In addition, the ratio of these "loops" and "trains" vary with the hydration level and with the length as well as sequence of the repetitive domain $[121,127,128]$. As the hydration level increases, 
the system is plasticized, allowing the orientation of $\beta$-turns in adjacent $\beta$-spirals to form structures that resemble an "interchain" $\beta$-sheet. Further extension will disrupt these "trains", while release from the extension will result in reformation of the equilibrium balance, resulting in elastic recoil. Support for this hypothesis comes from a study in which changes in gluten-protein conformation were determined by FTIR spectroscopy during protein deformation [128].

\section{Relationship to End Use Qualities}

It has been reported that different HMW-GSs affect the proportion of gluten secondary structures, and higher contents of $\beta$-sheets and $\beta$-turns of gluten are generally considered to be associated with better dough qualities [101,108,122,129]. A near-isogenic line with the highest content of $\beta$-turns was reported to yield the greatest dough viscoelasticity, while another with the highest content of $\beta$-sheets exhibited the greatest wheat dough strength. Meanwhile, it was also mentioned that significant differences in the secondary structures of different wheat lines were mainly caused by their HMW-GSs [129]. Similar results from another research reported that the proportion of secondary structure of gluten in three wheat near-isogenic lines mainly resulted from the different HMW-GS compositions encoded by Glu-A1 and Glu-D1 loci and that the content of $\beta$-sheets in gluten has a significant relationship with dough rheological properties [101]. Compared with the normal $\mathrm{Bx} 7$ subunits, $\mathrm{Bx} 7^{\mathrm{OE}}$ subunits of a wheat near-isogenic line were also reported to yield increased content of $\beta$-sheets in gluten secondary structure and were related to superior dough rheological properties [130]. Besides, HMW-GSs with higher content of $\beta$-strands, indicated by secondary structure prediction, may be helpful to form a better gluten structure [131]. A longer repetitive domain or a higher proportion of repeats units of HMW-GSs may produce more $\beta$-turns, which confer elasticity to the polymers and are supposed to be positively related to dough and bread-making qualities [33,132-136].

Currently, scholars hold different views on the effect of $\alpha$-helixes content on the dough quality. Compared with subunits from hexaploid wheat, subunits from TD-256, a cultivar with poor flour quality, possess less $\alpha$-helixes quantity according to a secondary structure prediction study [111]. This indicated that the $\alpha$-helixes content of HMW-GSs may exhibit positive effects on dough quality, supported by many other studies $[131,133]$. However, the content of $\alpha$-helixes of gluten was reported to be negatively correlated with that of $\beta$-sheets, which could be explained by the transformation between $\alpha$-helixes and $\beta$-sheets under certain conditions [122,129]. More $\alpha$-helixes lead to less $\beta$-sheets, and the latter correlates positively with dough quality. Scholars further argue that $\alpha$-helix content showed a negative correlation with dough quality [122]. In fact, significant correlations were found between the percentage of unextractable polymeric protein and the secondary structures mentioned above, so these secondary structures could be used as indicators for end product quality of dough [137].

\section{Conclusions}

HMW-GSs of wheat grain play a key role in determining rheological dough properties and end use properties. Both the interchain disulfide bonds and hydrogen bonds mediated by glutamine side chains are crucial for stabilizing the gluten structure. Specific alleles encoding HMW-GSs make greater contributions. In most cases, HMW-GSs with additional or less cysteines were supposed to give rise to relatively more or less formation of interchain disulfide bonds. As for secondary structures, HMW-GSs affect dough qualities by acting on the secondary structures' composition of gluten. Though cumulative work has been carried out for the relationship between the genetics/structures of HMW-GSs and dough end use qualities, it is essential to explore the mechanism of crosslinking via disulfide bonds among different types of HMW-GS and other gluten components more specifically to establish an accurate model for the role that HMW-GSs play in the dough. The number of cysteine residues, the length of the repetitive domain, and the secondary structure content could be used as predictors to evaluate the quality of novel HMW-GSs for molecular breeding. 
Meanwhile, more efforts should be made to transfer desirable Glu-1 alleles to cultivated wheat via hybridization and chromosomal engineering approaches.

Author Contributions: Conceptualization, Y.L., J.F., Q.S., and D.Y.; writing-original draft preparation, Y.L. and J.F.; writing-review and editing, Q.S. and D.Y. All authors have read and agreed to the published version of the manuscript.

Funding: This research was funded by the National Natural Science Foundation of China, grant number 31801482; by the National Key Research and Development Program of China, grant number 2019YFC1605000; and by the National Laboratory of Biomacromolecules, grant number 2018kf09.

Acknowledgments: The authors are grateful to Chih-chen Wang at the Institute of Biophysics, Chinese Academy of Sciences for her support and encouragement in our research.

Conflicts of Interest: The authors declare no conflict of interest.

\begin{tabular}{ll}
\multicolumn{2}{l}{ Abbreviations } \\
HMW-GS & High-molecular-weight glutenin subunit \\
SDS-PAGE & Sodium dodecyl sulfate-polyacrylamide gel electrophoresis \\
LMW-GS & Low-molecular-weight glutenin subunit \\
PCR & Polymerase chain reaction \\
GUS & ß-glucuronidase \\
Wis & Wheat insertion sequence \\
LTR & Long terminal repeat \\
1Dx5-N & N-terminal domain of 1Dx5 \\
LC-MS/MS & liquid chromatograph-mass spectrometer/mass spectrometry \\
GSH & glutathione \\
PSSG & protein bound glutathione \\
FTIR & Fourier transform infrared spectroscopy \\
NMR & Nuclear magnetic resonance
\end{tabular}

\section{References}

1. Agricultural Market Information System. Available online: http://www.amis-outlook.org/\#jfmulticontent_c363419-2 (accessed on 8 October 2020).

2. Organisation for Economic Co-operation and Development and Food and Agriculture Organization of United Nations Agricultural Outlook 2019-2028. Available online: https:/ / stats.oecd.org/viewhtml.aspx?datasetcode=HIGH_AGLINK_2019\&lang=en\# (accessed on 16 July 2019).

3. Anjum, F.M.; Khan, M.R.; Din, A.; Saeed, M.; Pasha, I.; Arshad, M.U. Wheat Gluten: High Molecular Weight Glutenin SubunitsStructure, Genetics, and Relation to Dough Elasticity. J. Food Sci. 2007, 72, R56-R63. [CrossRef] [PubMed]

4. Osborne, T.B. The Vegetable Proteins, 2nd ed.; Longmans Green and Co.: London, UK, 1924.

5. MacRitchie, F. Evaluation of Contributions from Wheat Protein Fractions to Dough Mixing and Breadmaking. J. Cereal Sci. 1987, 6, 259-268. [CrossRef]

6. MacRitchie, F. Physicochemical properties of wheat proteins in relation to functionality. Adv. Food Nutr. Res. 1992, 36, 1-87.

7. Weegels, P.L.; Hamer, R.J.; Schofield, J.D. Functional Properties of Wheat Glutenin. J. Cereal Sci. 1996, 23, 1-18. [CrossRef]

8. Wieser, H. Chemistry of gluten proteins. Food Microbiol. 2007, 24, 115-119. [CrossRef] [PubMed]

9. Lambourne, J.; Tosi, P.; Marsh, J.; Bhandari, D.; Green, R.; Frazier, R.; Shewry, P.R. Characterisation of an s-type low molecular weight glutenin subunit of wheat and its proline and glutamine-rich repetitive domain. J. Cereal Sci. 2010, 51, 96-104. [CrossRef]

10. Belton, P.S. Mini review: On the Elasticity of Wheat Gluten. J. Cereal Sci. 1999, 29, 103-107. [CrossRef]

11. D'Oovidio, R. The low-molecular-weight glutenin subunits of wheat gluten. J. Cereal Sci. 2004, 39, 321-339. [CrossRef]

12. Zhang, Q.; Dong, Y.M.; An, X.L.; Wang, A.; Zhang, Y.Z.; Li, X.H.; Gao, L.Y.; Xia, X.C.; He, Z.H.; Yan, Y.M. Characterization of HMW glutenin subunits in common wheat and related species by matrix-assisted laser desorption/ionization time-of-flight mass spectrometry (MALDI-TOF-MS). J. Cereal Sci. 2008, 47, 252-261. [CrossRef]

13. Liu, L.; Wang, A.L.; Appels, R.; Ma, J.H.; Xia, X.C.; Lan, P.; He, Z.H.; Bekes, F.; Yan, Y.M.; Ma, W.J. A MALDI-TOF based analysis of high molecular weight glutenin subunits for wheat breeding. J. Cereal Sci. 2009, 50, 295-301. [CrossRef]

14. Peng, Y.C.; Yu, K.; Zhang, Y.J.; Islam, S.; Sun, D.F.; Ma, W.J. Two novel y-type high molecular weight glutenin genes in Chinese wheat landraces of the Yangtze-River region. PLoS ONE 2015, 10, e0142348. [CrossRef] [PubMed]

15. Bietz, J.A.; Shepherd, K.W.; Wall, J.S. Single-kernel analysis of glutenin: Use in wheat genetics and breeding. Cereal Chem. 1975, 52, 513-532.

16. Payne, P.I.; Nightingale, M.A.; Krattiger, A.F.; Holt, L.M. The relationship between HMW glutenin subunit composition and the bread-making quality of British-grown wheat varieties. J. Sci. Food Agric. 1987, 40, 51-65. [CrossRef] 
17. Payne, P.I.; Holt, L.M.; Jackson, E.A.; Law, C. Wheat storage proteins: Their genetics and their potential for manipulation by plant breeding. Philos. Trans. R. Soc. Lond. B Biol. Sci. 1984, 304, 359-371.

18. Lawrence, G.J.; Shepherd, K.W. Chromosomal location of genes controlling seed proteins in species related to wheat. Theor. Appl. Genet. 1981, 59, 25-31. [CrossRef]

19. Payne, P.I.; Corfield, K.G.; Holt, L.M.; Blackman, J.A. Correlations between the inheritance of certain high-molecular weight subunits of glutenin and bread-making quality in progenies of six crosses of bread wheat. J. Sci. Food Agric. 1981, 32, 51-60. [CrossRef]

20. Payne, P.I.; Holt, L.M.; Lawrence, G.J.; Law, C.N. The genetics of gliadin and glutenin, the major storage proteins of the wheat endosperm. Plant Foods Hum. Nutr. 1982, 31, 229-241. [CrossRef]

21. Shewry, P.R.; Lafiandra, D.; Tamás, L.; Békés, F. Genetic manipulation of gluten structure and function. In Gliadin and Glutenin the Unique Balance of Wheat Quality; Wrigley, C., Békés, F., Bushuk, W., Eds.; American Association of Cereal Chemists, Inc. (AACC): St. Paul, MN, USA, 2006; pp. 363-385.

22. Thompson, R.D.; Bartels, D.; Harberd, N.P. Nucleotide sequence of a gene from chromosome $1 \mathrm{D}$ of wheat encoding a HMWglutenin subunit. Nucleic Acids Res. 1985, 13, 6833-6846. [CrossRef]

23. Halford, N.G.; Forde, J.; Anderson, O.D.; Greene, F.C.; Shewry, P.R. The nucleotide and deduced amino acid sequences of an HMW glutenin subunit gene from chromosome 1B of bread wheat (Triticum aestivum L.) and comparison with those of genes from chromosomes 1A and 1D. Theor. Appl. Genet. 1987, 75, 117-126. [CrossRef]

24. Payne, P.I.; Lawrence, G.J. Catalogue of alleles for the complex gene loci, Glu-A1, Glu-B1, and Glu-D1 which code for highmolecular-weight subunits of glutenin in hexaploid wheat. Cereal Res. Comm. 1983, 11, 29-35.

25. Shewry, P.R.; Gilbert, S.M.; Savage, A.W.; Tatham, A.S.; Wan, Y.F.; Belton, P.S.; Wellner, N.; D’Ovidio, R.; Bekes, F.; Halford, N.G. Sequence and properties of HMW subunit 1Bx20 from pasta wheat (Triticum durum) which is associated with poor end use properties. Theor. Appl. Genet. 2003, 106, 744-750. [CrossRef] [PubMed]

26. Wan, Y.; Wang, D.; Shewry, P.R.; Halford, N.G. Isolation and characterization of five novel high molecular weight subunit of glutenin genes from Triticum timopheevi and Aegilops cylindrica. Theor. Appl. Genet. 2002, 104, 828-839. [CrossRef] [PubMed]

27. Liu, Z.; Yan, Z.; Wan, Y.; Liu, K.; Zheng, Y.; Wang, D. Analysis of HMW glutenin subunits and their coding sequences in two diploid Aegilops species. Theor. Appl. Genet. 2003, 106, 1368-1378. [CrossRef] [PubMed]

28. Wang, H.Q.; Zhang, X.Y. An approach for isolating high-molecular-weight glutenin subunit genes using monoclonal antibodies. Genome 2006, 49, 181-189. [CrossRef]

29. McIntosh, R.A.; Yamazaki, Y.; Devos, K.M.; Dubcovsky, J.; Rogers, W.J.; Appels, R. Catalogue of gene symbols for wheat. In Proceedings of the 10th International Wheat Genetics Symposium, SIMI, Rome, Italy, 1-6 September 2003.

30. Bekes, F.; Cavanagh, C.R.; Martinov, S.; Bushuk, S.; Wrigley, C.W.F. PART II. Composition table for the HMW subunits of glutenin. In The Gluten Composition of Wheat Varieties and Genotypes; AACC International: St. Paul, MN, USA, 2008.

31. Li, X.; Liu, D.C.; Sun, J.Z.; Yang, W.L.; Guo, X.L.; Wang, D.W.; Zhang, A.M. Characterization of novel high-molecular-weight glutenin subunits and their coding sequences in Aegilops markgrafii. J. Cereal Sci. 2015, 65, 9-18. [CrossRef]

32. $\mathrm{Du}, \mathrm{X}$.; Zhang, X. Molecular cloning and functional characterization of two novel high molecular weight glutenin subunit genes in Aegilops markgrafii. J. Genet. 2017, 96, 563-570. [CrossRef]

33. Hou, W.Q.; Feng, W.; Yu, G.H.; Du, X.Y.; Ren, M.J. Cloning and functional analysis of a novel x-type high-molecular-weight glutenin subunit with altered cysteine residues from Aegilops umbellulata. Crop Pasture Sci. 2017, 68, 409-414. [CrossRef]

34. Hu, J.X.; Wang, J.; Deng, X.; Yan, Y.M. Cloning and characterization of special HMW glutenin subunit genes from Aegilops longissima L. and their potential for wheat quality improvement. 3 Biotech 2019, 9, 267. [CrossRef]

35. Wang, H.J.; Zhang, H.J.; Li, B.; Yu, Z.H.; Li, G.R.; Zhang, J.; Yang, Z.J. Molecular cytogenetic characterization of new wheatDasypyrum breviaristatum introgression lines for improving grain quality of wheat. Front. Plant Sci. 2018, 9, 365. [CrossRef]

36. Du, X.Y.; Jia, Z.; Yu, Y.; Wang, S.; Che, B.J.; Ni, F.; Bao, Y.G. A wheat-Aegilops umbellulata addition line improves wheat agronomic traits and processing quality. Breeding Sci. 2019, 69, 503-507. [CrossRef]

37. Yang, Y.H.; Li, S.M.; Zhang, K.P.; Dong, Z.Y.; Li, Y.W.; An, X.L.; Chen, J.; Chen, Q.F.; Jiao, Z.; Liu, X.; et al. Efficient isolation of ion beam-induced mutants for homoeologous loci in common wheat and comparison of the contributions of Glu-1 loci to gluten functionality. Theor. Appl. Genet. 2014, 127, 359-372. [CrossRef] [PubMed]

38. Lawrence, G.J.; MacRitchie, F.; Wrigley, C.W. Dough and baking quality of wheat lines deficient in glutenin subunits controlled by the Glu-A1, Glu-B1 and Glu-D1 loci. J. Cereal Sci. 1988, 7, 109-112. [CrossRef]

39. Zhang, L.J.; Chen, Q.F.; Su, M.J.; Yan, B.; Zhang, X.Q.; Jiao, Z. High-molecular-weight glutenin subunit-deficient mutants induced by ion beam and the effects of Glu-1 loci deletion on wheat quality properties. J. Food Sci. Agric. 2015, 96, 1289-1296. [CrossRef] [PubMed]

40. Jiang, P.H.; Xue, J.S.; Duan, L.N.; Gu, Y.S.; Mu, J.Y.; Han, S.C.; Chen, L.; Li, Y.X.; Ma, W.J.; Yan, Y.M.; et al. Effects of high-molecularweight glutenin subunit combination in common wheat on the quality of crumb structure. J. Sci. Food Agric. 2019, 99, 1501-1508. [CrossRef] [PubMed]

41. Brönneke, V.; Zimmermann, G.; Killermann, B. Effect of high molecular weight glutenins and D-zone gliadins on bread-making quality in German wheat varieties. Cereal Res. Commun. 2000, 28, 187-194. [CrossRef] 
42. Liu, H.Y.; Wang, K.; Xiao, L.L.; Wang, S.L.; Du, L.P.; Cao, X.Y.; Zhang, X.X.; Zhou, Y.; Yan, Y.M.; Ye, X.G. Comprehensive identification and bread-making quality evaluation of common wheat somatic variation line AS208 on glutenin composition. PLOS ONE 2016, 11, e0146933. [CrossRef]

43. Wang, Z.J.; Li, Y.W.; Yang, Y.H.; Liu, X.; Qin, H.J.; Dong, Z.Y.; Zheng, S.H.; Zhang, K.P.; Wang, D.W. New insight into the function of wheat glutenin proteins as investigated with two series of genetic mutants. Sci. Rep. 2017, 7, 1-14. [CrossRef]

44. Gao, X.; Liu, T.H.; Ding, M.Y.; Wang, J.; Li, C.L.; Wang, Z.H.; Li, X.J. Effects of HMW-GS Ax1 or Dx2 absence on the glutenin polymerization and gluten micro structure of wheat (Triticum aestivum L.). Food Chem. 2018, 240, 626-633. [CrossRef]

45. Song, L.J.; Li, L.Q.; Zhao, L.Y.; Liu, Z.Z.; Xie, T.T.; Li, X.J. Absence of Dx2 at Glu-D1 locus weakens gluten quality potentially regulated by expression of nitrogen metabolism enzymes and glutenin-related genes in wheat. Int. J. Mol. Sci. 2020, 21, 1383. [CrossRef]

46. Chen, H.Q.; Li, S.J.; Liu, Y.W.; Liu, J.X.; Ma, X.L.; Du, L.P.; Wang, K.; Ye, X.G. Effects of 1 Dy12 subunit silencing on seed storage protein accumulation and flour-processing quality in a common wheat somatic variation line. Food Chem. 2021, 335, 127663. [CrossRef]

47. Duan, L.N.; Han, S.C.; Wang, K.; Jiang, P.H.; Gu, Y.S.; Chen, L.; Mu, J.Y.; Ye, X.G.; Li, Y.X.; Yan, Y.M.; et al. Analyzing the action of evolutionarily conserved modules on HMW-GS 1Ax1 promoter activity. Plant Mol. Biol. 2019, 102, 225-237. [CrossRef] [PubMed]

48. Wang, K.; Zhang, X.; Zhao, Y.; Chen, F.G.; Xia, G.M. Structure, variation and expression analysis of glutenin gene promoters from Triticum aestivum cultivar Chinese Spring shows the distal region of promoter $1 B x 7$ is key regulatory sequence. Gene 2013, 527, 484-490. [CrossRef] [PubMed]

49. Ravel, C.; Fiquet, S.; Boudet, J.; Dardevet, M.; Vincent, J.; Merlino, M.; Michard, R.; Martre, P. Conserved cis-regulatory modules in promoters of genes encoding wheat high-molecular-weight glutenin subunits. Front. Plant Sci. 2014, 5, 621. [CrossRef] [PubMed]

50. Makai, S.; Éva, C.; Tamás, L.; Juhász, A. Multiple elements controlling the expression of wheat high molecular weight glutenin paralogs. Funct. Integr. Genomics 2015, 15, 661-672. [CrossRef] [PubMed]

51. Albani, D.; Hammond-Kosack, M.C.; Smith, C.; Conlan, S.; Colot, V.; Holdsworth, M.; Bevan, M.W. The Wheat Transcriptional Activator SPA: A Seed-Specific bZIP Protein That Recognizes the GCN4-like Motif in the Bifactorial Endosperm Box of Prolamin Genes. Plant Cell 1997, 9, 171-184.

52. Ravel, C.; Martre, P.; Romeuf, I.; Dardevet, M.; El-Malki, R.; Bordes, J.; Duchateau, N.; Brunel, D.; Balfourier, F.; Charmet, G. Nucleotide polymorphism in the wheat transcriptional activator Spa influences its pattern of expression and has pleiotropic effects on grain protein composition, dough viscoelasticity, and grain hardness. Plant Physiol. 2009, 151, 2133-2144. [CrossRef]

53. Kumar, A.; Jaiswal, J.P.; Sharma, N.; Gupta, S.; Kumar, A. Understanding the molecular basis of differential grain protein accumulation in wheat (Triticum aestivum L.) through expression profiling of transcription factors related to seed nutrients storage. 3 Biotech 2018, 8, 112. [CrossRef]

54. Guo, D.D.; Hou, Q.L.; Zhang, R.Q.; Lou, H.Y.; Li, Y.H.; Zhang, Y.F.; You, M.S.; Xie, C.J.; Liang, R.Q.; Li, B.Y. Over-Expressing TaSPA-B Reduces Prolamin and Starch Accumulation in Wheat (Triticum aestivum L.) Grains. Int. J. Mol. Sci. 2020, $21,3257$. [CrossRef]

55. Boudet, J.; Merlino, M.; Plessis, A.; Gaudin, J.C.; Dardevet, M.; Perrochon, S.; Alvarez, D.; Risacher, T.; Martre, P.; Ravel, C. The bZIP transcription factor SPA Heterodimerizing Protein represses glutenin synthesis in Triticum aestivum. Plant J. 2019, 97, 858-871. [CrossRef]

56. Johansson, E.; Henriksson, P.; Svensson, G.; Heneen, W. Detection, chromosomal location and evaluation of the functional value of a novel high Mr glutenin subunit found in Swedish wheats. J. Cereal Sci. 1993, 17, 237-245. [CrossRef]

57. Margiotta, B.; Urbano, M.; Colaprico, G.; Johansson, E.; Buonocore, F.; D'Ovidio, R.; Lafiandra, D. Detection of y-type subunit at the Glu-A1 locus in some Swedish bread wheat lines. J. Cereal Sci. 1996, 23, 203-212. [CrossRef]

58. Anjum, F.M.; Lookhart, G.L.; Walker, C.E. Electrophoretic identification of hard white spring wheats grown at different locations in Pakistan in different years. J. Sci. Food Agric. 2000, 80, 1155-1161. [CrossRef]

59. Ciaffi, M.; Lafiandra, D.; Porceddu, E.; Benedettelli, S. Storage-protein variation in wild emmer wheat (Triticum turgidum ssp. dicoccoides) from Jordan and Turkey. I. Electrophoretic characterization of genotypes. Theor. Appl. Genet. 1993, 86, 474-480.

60. Jiang, Q.T.; Ma, J.; Zhao, S.; Zhao, Q.Z.; Lan, X.J.; Dai, S.F.; Lu, Z.X.; Zheng, Y.L.; Wei, Y.M. Characterization of HMW-GSs and their gene inaction in tetraploid wheat. Genetica 2012, 140, 325-335. [CrossRef] [PubMed]

61. Luo, G.B.; Song, S.Y.; Zhao, L.R.; Shen, L.S.; Song, Y.H.; Wang, X.; Yu, K.; Liu, Z.Y.; Li, Y.W.; Yang, W.L. Mechanisms, origin and heredity of Glu-1Ay silencing in wheat evolution and domestication. Theor. Appl. Genet. 2018, 131, 1561-1575. [CrossRef] [PubMed]

62. Harberd, N.P.; Flavell, R.B.; Thompson, R.D. Identification of a transposon-like insertion in a Glu-1 allele of wheat. Mol. Gen. Genet. 1987, 209, 326-332. [CrossRef] [PubMed]

63. Sun, M.M.; Yan, Y.M.; Jiang, Y.; Xiao, Y.H.; Hu, Y.K.; Cai, M.H.; Li, Y.X.; Hsam, S.L.K.; Zeller, F.J. Molecular cloning and comparative analysis of a y-type inactive HMW glutenin subunit gene from cultivated emmer wheat (Triticum dicoccum L.). Hereditas 2004, 141, 46-54. [CrossRef]

64. Jiang, Q.T.; Wei, Y.M.; Wang, F.; Wang, J.R.; Yan, Z.H.; Zheng, Y.L. Characterization and comparative analysis of HMW glutenin 1Ay alleles with differential expressions. BMC Plant Biol. 2009, 9, 16. [CrossRef]

65. Gu, Y.Q.; Coleman-Derr, D.; Kong, X.Y.; Anderson, O.D. Rapid genome evolution revealed by comparative sequence analysis of orthologous regions from four triticeae genomes. Plant Physiol. 2004, 135, 459-470. [CrossRef] 
66. Wang, Z.Z.; Huang, L.; Wu, B.H.; Hu, J.L.; Jiang, Z.L.; Qi, P.F.; Zheng, Y.L.; Liu, D.C. Characterization of an Integrated Active Glu-1Ay Allele in Common Wheat from Wild Emmer and Its Potential Role in Flour Improvement. Int. J. Mol. Sci. 2018, 19, 923. [CrossRef]

67. Roy, N.; Islam, S.; Ma, J.; Lu, M.; Torok, K.; Tomoskozi, S.; Bekes, F.; Lafiandra, D.; Appels, R.; Ma, W.J. Expressed Ay HMW glutenin subunit in Australian wheat cultivars indicates a positive effect on wheat quality. J. Cereal Sci. 2017, 79, 494-500. [CrossRef]

68. Roy, N.; Islam, S.; Yu, Z.T.; Lu, M.Q.; Lafiandra, D.; Zhao, Y.; Anwar, M.; Mayer, J.E.; Ma, W.J. Introgression of an expressed HMW 1 Ay glutenin subunit allele into bread wheat cv. Lincoln increases grain protein content and breadmaking quality without yield penalty. Theor. Appl. Genet. 2019, 133, 517-528. [CrossRef] [PubMed]

69. Marchylo, B.A.; Lukow, O.M.; Kruger, J.E. Quantitative variation in high molecular weight glutenin subunit 7 in some Canadian wheats. J. Cereal Sci. 1992, 15, 29-37. [CrossRef]

70. Lukow, O.M.; Forsyth, S.A.; Payne, P.I. Over-production of HMW [High Molecular Weight] glutenin subunits coded on chromosome 1B in common wheat-Triticum aestivum [in Israel and Canada]. J. Genet. Breeding Sci. 1992, 46, 187-192.

71. D'Ovidio, R.; Masci, S.; Porceddu1, E.; Kasarda, D.D. Duplication of the Bx7 high-molecular-weight glutenin subunit gene in bread wheat (Triticum aestivum L.) cultivar'Red River 68'. Plant Breeding 1997, 116, 525-531. [CrossRef]

72. Juhàsz, A.; Larroque, O.R.; Tamas, L.; Hsam, S.L.K.; Zeller, F.J.; Békés, F.; Bedo, Z. Bánkúti 1201-an old Hungarian wheat variety with special storage protein composition. Theor. Appl. Genet. 2003, 107, 697-704. [CrossRef]

73. Radovanovic, N.; Cloutier, S.; Brown, D.; Humphreys, D.G.; Lukow, O.M. Genetic Variance for Gluten Strength Contributed by High Molecular Weight Glutenin Proteins. Cereal Chem. 2002, 79, 843-849. [CrossRef]

74. Gao, X.; Appelbee, M.J.; Mekuria, G.T.; Chalmers, K.J.; Mather, D.E. A second 'overexpression' allele at the Glu-B1 high-molecularweight glutenin locus of wheat: Sequence characterisation and functional effects. Theor. Appl. Genet. 2012, 124, 333-343. [CrossRef]

75. Butow, B.J.; Gras, P.W.; Haraszi, R.; Bekes, F. Effects of different salts on mixing and extension parameters on a diverse group of wheat cultivars using 2-g mixograph and extensigraph methods. Cereal Chem. 2002, 79, 826-833. [CrossRef]

76. Butow, B.J.; Ma, W.; Gale, K.R.; Cornish, G.B.; Rampling, L.; Larroque, O.; Morell, M.K.; Bekes, F. Molecular discrimination of Bx7 alleles demonstrates that a highly expressed high molecular weight glutenin allele has a major impact on wheat flour dough strength. Theor. Appl. Genet. 2003, 107, 1524-1532. [CrossRef]

77. Ragupathy, R.; Naeem, H.A.; Reimer, E.; Lukow, O.M.; Sapirstein, H.D.; Cloutier, S. Evolutionary origin of the segmental duplication encompassing the wheat GLU-B1 locus encoding the overexpressed $\mathrm{B} \times 7$ ( $\mathrm{B} \times 7 \mathrm{OE})$ high molecular weight glutenin subunit. Theor. Appl. Genet. 2007, 116, 283-296. [CrossRef] [PubMed]

78. Cloutier, S.; Banks, T.; Nilmalgoda, S. Molecular understanding of wheat evolution at the Glu-B1 locus. In Proceedings of the International Conference on Plant Genomics and Biotechnology: Challenges and Opportunities, Raipur, India, 26-28 October 2005; p. 40.

79. Shewry, P.R.; Halford, N.G.; Tatham, A.S. High molecular weight subunits of wheat glutenin. J. Cereal Sci. 1992, 15, 105-120 [CrossRef]

80. Tatham, A.S.; Drake, A.F.; Shewry, P.R. Conformational studies of synthetic peptides corresponding to the repetitive regions of the high molecular weight (HMW) glutenin subunits of wheat. J. Cereal Sci. 1990, 11, 189-200. [CrossRef]

81. Shewry, P.R.; Halford, N.G.; Tatham, A.S. The high molecular weight subunits of wheat, barley and rye: Genetics, molecular biology, chemistry and role in wheat gluten structure and functionality. In Oxford Surveys of Plant and Molecular Cell Biology; Miflin, B.J., Ed.; Oxford University Press: London, UK, 1989; pp. 163-219.

82. Anderson, O.D.; Greene, F.C. The characterization and comparative analysis of high-molecular-weight glutenin genes from genomes A and B of a hexaploid bread wheat. Theor. Appl. Genet. 1989, 77, 689-700. [CrossRef] [PubMed]

83. Shewry, P.R.; Halford, N.G.; Tatham, A.S.; Popineau, Y.; Lafiandra, D.; Belton, P.S. The high molecular weight subunits of wheat glutenin and their role in determining wheat processing properties. Adv. Food Nutr. Res. 2003, 45, 219-302. [PubMed]

84. D'Ovidio, R.; Masci, S.; Porceddu, E. Development of a set of oligonucleotide primers specific for genes at the Glu-1 complex loci of wheat. Theor. Appl. Genet. 1995, 91, 189-194. [CrossRef]

85. Halford, N.G.; Field, J.M.; Blair, H.; Urwin, P.; Moore, K.; Robert, L.; Thompson, R.; Flavell, R.B.; Tatham, A.S.; Shewry, P.R. Analysis of HMW glutenin subunits encoded by chromosome 1A of bread wheat (Triticum aestivum L.) indicates quantitative effects on grain quality. Theor. Appl. Genet. 1992, 83, 373-378. [CrossRef]

86. Gao, J.H.; Yu, P.X.; Liang, H.R.; Fu, J.H.; Luo, Z.Y.; Yang, D. The wPDI Redox Cycle Coupled Conformational Change of the Repetitive Domain of the HMW-GS 1Dx5-A Computational Study. Molecules 2020, 25, 4393. [CrossRef]

87. Anderson, O.D.; Greene, F.C.; Yip, R.E.; Halford, N.G.; Shewry, P.R.; Malpica-Romero, J. Nucleotide sequences of the two high-molecular-weight glutenin genes from the D-genome of a hexaploid bread wheat, Triticum aestivum L. cv Cheyenne. Nucleic Acids Res. 1989, 17, 461-462. [CrossRef]

88. Kasarda, D.D. Glutenin structure in relation to wheat quality. In Wheat is Unique; Pomeranz, Y., Ed.; AACC: St. Paul, MN, USA, 1989; Volume 277, pp. 277-302.

89. Buonocore, F.; Caporale, C.; Lafiandra, D. Purification and Characterisation of High Mr Glutenin Subunit 20 and its Linked y-type Subunit from Durum Wheat. J. Cereal Sci. 1996, 23, 195-201. [CrossRef] 
90. Li, W.; Wan, Y.; Liu, Z.; Liu, K.; Liu, X.; Li, B.; Li, Z.; Zhang, X.; Dong, Y.; Wang, D. Molecular characterization of HMW glutenin subunit allele 1Bx14: Further insights into the evolution of Glu-B1-1 alleles in wheat and related species. Theor. Appl. Genet. 2004, 109, 1093-1104. [CrossRef] [PubMed]

91. Tatham, A.S.; Field, J.M.; Keen, J.N.; Jackson, P.J.; Shewry, P.R. Purification and characterization of HMW glutenin subunits encoded by chromosome 1B of durum wheat (Triticum durum). J. Cereal Sci. 1991, 14, 111-116. [CrossRef]

92. Grosch, W.; Wieser, H. Redox Reactions in Wheat Dough as Affected by Ascorbic Acid. J. Cereal Sci. 1999, 29, 1-16. [CrossRef]

93. Wrigley, C.W. Giant proteins with flour power. Nature 1996, 72, 738-739. [CrossRef]

94. Wang, L.; Yu, J.J.; Wang, C.C. Protein disulfide isomerase is regulated in multiple ways: Consequences for conformation, activities, and pathophysiological functions. BioEssays 2020. [CrossRef]

95. Wieser, H. The use of redox agents in breadmaking. In Breadmaking, 2nd ed.; Cauvain, S.P., Ed.; Woodhead Publishing: Sawston, UK, 2012; pp. 447-469.

96. Shewry, P.R.; Popineau, Y.; Lafiandra, D.; Belton, P. Wheat glutenin subunits and dough elasticity: Findings of the EUROWHEAT project. Trends Food Sci. Technol. 2001, 11, 433-441. [CrossRef]

97. Humphris, A.D.L.; McMaster, T.J.; Miles, M.J.; Gilbert, S.M.; Shewry, P.R.; Tatham, A.S. Atomic Force Microscopy (AFM) Study of Interactions of HMW Subunits of Wheat Glutenin. Cereal Chem. 2000, 77, 107-110. [CrossRef]

98. Zhao, C.F.; Luo, Z.Y.; Li, M.Z.; Gao, J.H.; Liang, Z.X.; Sun, S.Y.; Wang, X.; Yang, D. Wheat protein disulfide isomerase improves bread properties via different mechanisms. Food Chem. 2020, 315, 126242. [CrossRef]

99. Lindsay, M.P.; Tamas, L.; Appels, R.; Skerritt, J.H. Direct Evidence that the Number and Location of Cysteine Residues affect Glutenin Polymer Structure. J. Cereal Sci. 2000, 31, 321-333. [CrossRef]

100. Ferrer, E.G.; Gómez, A.V.; Añón, M.C.; Puppo, M.C. Structural changes in gluten protein structure after addition of emulsifier. A Raman spectroscopy study. Spectrochimi. Acta A 2011, 79, 278-281. [CrossRef]

101. Li, X.J.; Liu, T.H.; Song, L.J.; Zhang, H.; Li, L.Q.; Gao, X. Influence of high-molecular-weight glutenin subunit composition at Glu-A1 and Glu-D1 loci on secondary and micro structures of gluten in wheat (Triticum aestivum L.). Food Chem. 2016, 213, 728-734. [CrossRef] [PubMed]

102. Keck, B.; Köhler, P.; Wieser, H. Disulphide bonds in wheat gluten: Cystine peptides derived from gluten proteins following peptic and thermolytic digestion. Z. Lebensm. Unters. F. 1995, 200, 432-439. [CrossRef] [PubMed]

103. Lutz, E.; Wieser, H.; Koehler, P. Identification of disulfide bonds in wheat gluten proteins by means of mass spectrometry/electron transfer dissociation. J. Agric. Food Chem. 2012, 60, 3708-3716. [CrossRef] [PubMed]

104. Köhler, P.; Belitz, H.-D.; Wieser, H. Disulphide bonds in wheat gluten: Further cystine peptides from high molecular weight (HMW) and low molecular weight (LMW) subunits of glutenin and from $\gamma$-gliadins. Z. Lebensm. Unters. F. 1993, 196, 239-247. [CrossRef] [PubMed]

105. Köhler, P.; Bettina, K.G.; Wieser, H.; Kasarda, D.D. Molecular Modeling of the N-terminal Regions of High Molecular Weight Glutenin Subunits 7 and 5 in Relation to Intramolecular Disulfide Bond Formation. Cereal Chem. 1997, 74, 154-158. [CrossRef]

106. Cazalis, R.; Aussenac, T.; Rhazi, L.; Marin, A.; Gibrat, J.F. Homology modeling and molecular dynamics simulations of the N-terminal domain of wheat high molecular weight glutenin subunit 10. Protein Sci. 2003, 12, 34-43. [CrossRef] [PubMed]

107. Wang, J.J.; Liu, G.; Huang, Y.B.; Zeng, Q.H.; Hu, S.Q. Dissecting the disulfide linkage of the N-terminal domain of HMW 1Dx5 and its contributions to dough functionality. J. Agric. Food Chem. 2017, 65, 6264. [CrossRef]

108. Wang, J.J.; Liu, G.; Huang, Y.B.; Zeng, Q.H.; Song, G.S.; Hou, Y.; Li, L.; Hu, S.Q. Role of N-terminal domain of HMW 1Dx5 in the functional and structural properties of wheat dough. Food Chem. 2016, 213, 682-690. [CrossRef]

109. Popineau, Y.; Deshayes, G.; Lefebvre, J.; Fido, R.; Tatham, A.S.; Shewry, P.R. Prolamin aggregation, gluten viscoelasticity, and mixing properties of transgenic wheat lines expressing 1Ax and 1Dx high molecular weight glutenin subunit transgenes. J. Agric. Food Chem. 2001, 49, 395-401. [CrossRef]

110. Margiotta, B.; Pfluger, L.; Roth, M.R.; MacRitchie, F.; Lafiandra, D. Isogenic bread wheat lines differing in number and type of high Mr glutenin subunits. In Proceedings of the 7th International Workshop Gluten 2000, Bristol, UK, 2-6 April 2000; pp. 29-33.

111. Zhang, D.L.; He, T.T.; Liang, H.H.; Huang, L.Y.; Su, Y.Z.; Li, Y.G.; Li, S.P. Flour quality and related molecular characterization of high molecular weight glutenin subunit genes from wild emmer wheat accession TD-256. J. Agric. Food Chem. 2016, 64, 5128-5136. [CrossRef]

112. Joye, I.J.; Lagrain, B.; Delcour, J.A. Endogenous redox agents and enzymes that affect protein network formation during breadmaking-A review. J. Cereal Sci. 2009, 50, 1-10. [CrossRef]

113. Li, W.L.; Tsiami, A.A.; Schofield, J.D. Redox Reactions during Dough Mixing and Dough Resting: Effect of Reduced and Oxidised Glutathione and L-Ascorbic Acid on Rheological Properties of Gluten. In Wheat Gluten; Shewry, P.R., Tatham, A.S., Eds.; The Royal Society of Chemistry: Cambridge, UK, 2000; pp. 239-243.

114. Gilbert, S.M.; Wellner, N.; Belton, P.S.; Greenfield, J.A.; Siligardi, G.; Shewry, P.R.; Tatham, A.S. Expression and characterisation of a highly repetitive peptide derived from a wheat seed storage protein. BBA-Protein Struct. Mol. Enzym. 2000, 1479, 135-146. [CrossRef]

115. Tatham, A.S.; Shewry, P.R.; Miflin, B.J. Wheat gluten elasticity: A similar molecular basis to elastin? FEBS Lett. 1984, 177, 205-208. [CrossRef]

116. Tatham, A.S.; Miflin, B.J.; Shewry, P.R. The $\beta$-turn conformation in wheat gluten proteins: Relationship to gluten elasticity. Cereal Chem. 1985, 62, 405-412. 
117. Van Dijk, A.A.; Van Wijk, L.L.; Van Swieten, E.; Robillard, G.T.; Vliet, A.V.; Tesser, G.I.; Haris, P. Structure characterization of the central repetitive domain of high molecular weight gluten proteins. I. Model studies using cyclic and linear peptides. Protein Sci. 1997, 6, 637-648. [CrossRef]

118. Miles, M.J.; Carr, H.J.; McMaster, T.C.; I'Anson, K.J.; Belton, P.S.; Morris, V.J.; Field, J.M.; Shewry, P.R.; Tatham, A.S. Scanning tunneling microscopy of a wheat seed storage protein reveals details of an unusual supersecondary structure. PNAS 1991, 88, 68-71. [CrossRef]

119. Field, J.M.; Tatham, A.S.; Shewry, P.R. The structure of a high-Mr subunit of durum-wheat (Triticum durum) gluten. Biochem. J. 1987, 247, 215-221. [CrossRef]

120. Matsushima, N.; Danno, G.I.; Sasaki, N.; Izumi, Y. Small-angle X-ray scattering study by synchrotron orbital radiation reveals that high molecular weight subunit of glutenin is a very anisotropic molecule. Biochem. Biophys. Res. Commun. 1992, 186, 1057-1064. [CrossRef]

121. Belton, P.S.; Colquhoun, I.J.; Grant, A.; Wellner, N.; Field, J.M.; Shewry, P.R.; Tatham, A.S. FTIR and NMR studies on the hydration of a high-Mr subunit of glutenin. Int. J. Biol. Macromol. 1995, 17, 74-80. [CrossRef]

122. Georget, D.M.R.; Belton, P.S. Effects of temperature and water content on the secondary structure of wheat gluten studied by FTIR spectroscopy. Biomacromolecules 2006, 7, 469-475. [CrossRef]

123. Belton, P.S. A hypothesis concerning the elasticity of high molecular weight subunits. In Wheat Kernel Proteins: Molecular Functional Aspects; Universita della Tuscia: Viterbo, Italy, 1994; pp. 159-165.

124. Mita, T.; Matsumoto, H. Flow properties of aqueous gluten and gluten methyl ester dispersions. Cereal Chem. 1981, 58, 57-61.

125. Bushuk, W. Interactions in wheat doughs. In The Keys to Cereal Quality; American Assn. of Cereal Chemists: St. Paul, MN, USA, 1998; pp. 1-16.

126. Alberti, E.; Gilbert, S.M.; Tatham, A.S.; Shewry, P.R.; Gil, A.M. Study of high molecular weight wheat glutenin subunit 1Dx5 by ${ }^{13} \mathrm{C}$ and ${ }^{1} \mathrm{H}$ solid-state NMR spectroscopy. I. Role of covalent crosslinking. Biopolymers 2002, 67, 487-498. [CrossRef] [PubMed]

127. Feeney, K.A.; Wellner, N.; Gilbert, S.M.; Halford, N.G.; Tatham, A.S.; Shewry, P.R.; Belton, P.S. Molecular structures and interactions of repetitive peptides based on wheat glutenin subunits depend on chain length. Biopolymers 2003, 72, 123-131. [CrossRef] [PubMed]

128. Wellner, N.; Mills, E.N.C.; Brownsey, G.; Wilson, R.H.; Brown, N.; Freeman, J.; Halford, N.G.; Shewry, P.R.; Belton, P.S. Changes in Protein Secondary Structure during Gluten Deformation Studied by Dynamic Fourier Transform Infrared Spectroscopy. Biomacromolecules 2005, 6, 255-261. [CrossRef] [PubMed]

129. Gao, X.; Liu, T.H.; Yu, J.; Li, L.Q.; Feng, Y.; Li, X.J. Influence of high-molecular-weight glutenin subunit composition at Glu-B1 locus on secondary and micro structures of gluten in wheat (Triticum aestivum L.). Food Chem. 2016, 197, 1184-1190. [CrossRef] [PubMed]

130. Li, S.P.; Liu, Y.C.; Tong, J.Y.; Yu, L.W.; Ding, M.Y.; Zhang, Z.M.; Rehman, A.-u.; Majzoobi, M.; Wang, Z.H.; Gao, X. The overexpression of high-molecular-weight glutenin subunit Bx7 improves the dough rheological properties by altering secondary and micro-structures of wheat gluten. Food Res. Int. 2020, 130, 108914. [CrossRef]

131. Jin, M.; Xie, Z.Z.; Ge, P.; Li, J.; Jiang, S.S.; Subburaj, S.; Li, X.H.; Zeller, F.J.; Hsam, S.L.K.; Yan, Y.M. Identification and molecular characterisation of HMW glutenin subunit 1By16* in wild emmer. J. Appl. Genet. 2012, 53, 249-258. [CrossRef]

132. Flavell, R.B.; Goldsbrough, A.P.; Robert, L.S.; Schnick, D.; Thompson, R.D. Genetic variation in wheat HMW glutenin subunits and the molecular basis of bread-making quality. Bio/Technology 1989, 7, 1281-1285. [CrossRef]

133. Wang, K.; An, X.L.; Pan, L.P.; Dong, K.; Gao, L.Y.; Wang, S.L.; Xie, Z.Z.; Zhang, Z.; Appels, R.; Ma, W.; et al. Molecular characterization of HMW-GS $1 \mathrm{D} \times 3^{\mathrm{t}}$ and $1 \mathrm{D} \times 4^{\mathrm{t}}$ genes from Aegilops tauschii and their potential value for wheat quality improvement. Hereditas 2012, 149, 41-49. [CrossRef]

134. Wang, S.; Yu, Z.T.; Cao, M.; Shen, X.X.; Li, N.; Li, X.H.; Ma, W.J.; Weißgerber, H.; Zeller, F.; Hsam, S.; et al. Molecular mechanisms of HMW glutenin subunits from $1 S^{1}$ genome of Aegilops longissima positively affecting wheat breadmaking quality. PLoS ONE 2013, 8, e58947. [CrossRef]

135. Gianibelli, M.C.; Larroque, O.R.; MacRitchie, F.; Wrigley, C.W. Biochemical, Genetic, and Molecular Characterization of Wheat Glutenin and Its Component Subunits. Cereal Chem. 2001, 78, 635-646. [CrossRef]

136. Li, X.Y.; Li, Y.; Karim, H.; Li, Y.; Zhong, X.J.; Tang, H.P.; Qi, P.F.; Ma, J.; Wang, J.R.; Chen, G.Y.; et al. The production of wheat-Aegilops sharonensis $1 S^{\text {sh }}$ chromosome substitution lines harboring alien novel high-molecular-weight glutenin subunits. Genome 2019, 63, 155-167. [CrossRef] [PubMed]

137. Liu, T.; Gao, X.; Li, L.; Du, D.; Cheng, X.; Zhao, Y.; Liu, Y.; Li, X. Effects of HMW-GS at Glu-B1 locus on the polymerization of glutenin during grain development and on the secondary and micro-structures of gluten in wheat (Triticum aestivum L.). J. Cereal Sci. 2016, 72, 101-107. [CrossRef] 